\title{
What do students think about SNSs in education? University students' perceptions, expectations and concerns regarding educational uses of SNSs
}

\author{
Murat Akçayır \\ Kırıkkale University, Turkey
}

\begin{abstract}
Social network sites (SNSs) have become a popular technology in recent years and are currently used in educational environments. Although SNSs have attracted much scholarly attention, students' experiences with and expectations about SNS uses in education have not been deeply explored. This study investigates educational uses of SNSs by analysing university students' perceptions, experiences, expectations and concerns. A mixed method approach was used. The participants were 206 Turkish university students aged 18-28. As a quantitative data collection tool, Lim and Richardson's (2016) social networking use survey was employed. To better understand the students' perceptions, expectations and concerns about using SNSs for educational purposes, face-to-face semi-structured interviews were conducted with 58 participants. The results of the study reveal that the students actively used SNSs for different purposes. The participants also exhibited positive perceptions of SNS use for educational purposes. Among the biggest expectations is that instructors would share materials using SNSs. When the students' general expectations were examined, notably different results were obtained. The greatest concern of the students was that their personal posts could be seen by their instructors.
\end{abstract}

\section{Introduction}

Social network sites (SNSs) are a very popular Internet-based technology. While in their early years the primary purpose of SNSs was socialising (Madge, Meek, Wellens, \& Hooley, 2009), the use of SNSs for educational purposes has now become widespread (Weisgerber \& Butler, 2010). In 2008, educational uses of SNSs accounted for only $8 \%$ to $10 \%$ of their total usage (Ajjan \& Hartshorne, 2008; Raacke \& BondsRaacke, 2008). This percentage has since significantly increased (Sánchez, Cortijo, \& Javed, 2014). Due to reasons such as students spending a lot of time on SNSs, not experiencing any problems with their use, and free connections to SNSs, these sites are thought to offer many opportunities for education (Arnold \& Paulus, 2010). Today, SNSs are used in all levels of schooling, from K-12 (Khan, Wohn, \& Ellison, 2014) to higher education (Junco, Heiberger, \& Loken, 2011).

There has been a large increase in scholarly research which focuses on the uses of SNSs in education (Manca \& Ranieri, 2013, 2016). This research demonstrates that SNSs can be used successfully in many ways by educators (Callaghan \& Bower, 2012). For instance, SNSs can increase the interaction between students and their instructors (Aydin, 2014). By means of SNSs, instructors can easily communicate with their students (Fewkes \& McCabe, 2012). SNSs also can be utilised for both informal and formal education (Madge et al., 2009).

In the literature, apart from the topic of educational facilities offered by SNSs, some scholars also have investigated concerns among users who must employ SNSs for education (Gettman \& Cortijo, 2015). For example, students tend to regard SNS as social tools rather than as formal teaching tools; thus, they are not always eager to use them for the purpose of formal education (Baran, 2010; Gettman \& Cortijo, 2015). Students' privacy concerns are another obstacle to the use of SNSs for educational purposes (Feng \& Xie, 2014).

The contradictory nature of these findings indicates that there is a need for a better understanding of whether and precisely how to use SNSs in education. The perspectives of students should be further investigated, so that educators may use SNSs more efficiently and with less student resistance. 


\section{Literature review}

The definition of SNSs

There are several definitions of SNSs in the literature (Akçayır \& Akçayır, 2016). One of the earlier definitions by Bartlett-Bragg (2006) is a "range of applications that augments group interactions and shared spaces for collaboration, social connections, and aggregates information exchanges in a web-based environment” (p. 3). Other definitions in the literature include that of Merchant (2012): "The social network is a way of conceptualising social groupings and interaction" (p. 5). This definition emphasises interaction. Similarly, Park, Cha, Lim, and Jung's (2014) definition of SNSs is "social networking services are webbased services or communities that emphasise Internet-based interactions grounded in social relations” (p. 1). This also emphasises interaction and draws attention to social relations.

According to Reiners and Alexander (2013), the most widely accepted definition of SNSs is that by Boyd and Ellison (2008): "SNS are web-based services that allow individuals to (1) construct a public or semipublic profile within a bounded system, (2) articulate a list of other users with whom they share a connection, and (3) view and traverse their list of connections and those made by others within the system" (p. 211). This differs from other definitions in the literature in that it is mostly based on the functions of SNSs.

\section{SNSs in education}

Facebook, Twitter and YouTube are the most used SNSs in education (Akçayır \& Akçayır, 2016). One of the most popular SNSs in the world, Facebook, had 1.65 billion active users world-wide in the first quarter of 2016 (Statista, 2016). Over time, Facebook began to be used in education and has become the most frequently used SNSs in educational studies (Akçayır \& Akçayır, 2016). Consequently, many researchers have investigated its educational uses (e.g., Junco, 2012; Khan et al., 2014; Roblyer, McDaniel, Webb, Herman, \& Witty, 2010; Wang, Woo, Quek, Yang, \& Liu, 2012). Following Facebook, the next most popular SNSs for educational uses are Twitter and YouTube (Akçayır \& Akçayır, 2016). Twitter is an example of a micro blogging tool (Fox \& Varadarajan, 2011) which combines instant messaging and blogging (Pervaiz, 2016) and is more amenable to an ongoing, public dialogue than other SNSs with this feature (Junco et al., 2011). As a video resource, YouTube facilitates education especially in fields such as music education and psychomotor skills instruction (Akçayır \& Akçayır, 2016). Apart from these three dominant SNSs, others such as Bebo (Dowdall, 2009), Ning (Casey, 2013) and Edmodo (Krutka, Bergman, Flores, Mason, \& Jack, 2014) are used in education and have shown productive results.

A review of the literature on the use of SNSs in education shows that despite their continuing popularity, the educational value of SNSs has not been fully determined (Manca \& Ranieri, 2013). Based upon the literature, SNSs offer much that can enhance educational goals. For example, they can be used to increase collaboration among students (Greenhow, Robelia, \& Hughes, 2009) and to increase student-teacher interactions (Aydin, 2014). However, although most researchers have found that SNSs are potentially effective educational tools (e.g., Ebner, Lienhardt, Rohs, \& Meyer, 2010; Sánchez et al., 2014), others have cautioned against using them for educational purposes (Selwyn, 2009). Regarding students' reactions to the use of SNSs as educational tools, some studies have found contrasting results (Manca \& Ranieri, 2013). Backer (2010) found that $92 \%$ of the participating students reported that their uses of SNSs increased their motivation, independent learning and sense of responsibility. But another study, by Baran (2010), concluded that almost half of the students were not yet ready to accept the use of SNSs in formal teaching, learning or assessment. Similarly, Madge et al.’s (2009) results highlight that while most university students use Facebook in their daily lives, they definitely do not use it for formal educational purposes. They found that only $10 \%$ of their participating students used Facebook to discuss academic work, and only $1 \%$ used it to contact faculty members. Madge et al. suggested that since the students were reluctant to use Facebook for academic purposes, this SNSs should not be employed for educational uses but rather as a "social glue" for socialisation. Greenhow and Robelia (2009) and Selwyn and Grant (2009) concluded that their participating students generally perceived SNSs as social technologies and not as educational tools. According to Davies and Sant (2014), their participating teachers could not effectively use SNSs for education due to their lack of detailed knowledge of what their students were doing on SNSs; this meant that they could not assess whether their assigned SNS activities might lead to desired educational outcomes. Therefore, evidence is still needed regarding students' activities on SNSs, their perceptions of SNSs as academic tools (Sánchez et al., 2014) and their expectations regarding educational uses of SNSs. In another 
words, "before we can realize the benefits of technology, we must better understand our students and how they use technology” (Kalin, 2012, p. 3).

Some studies indicate that students are not comfortable using SNSs in education because of certain drawbacks (Issa, Isaias, \& Kommers, 2016). For example, Davies and Sant (2014) conducted a study with young (aged 12-16) British students and found that they worried about many things, such as the difficulty of verifying information presented through SNSs and how SNSs might be harmfully addictive for them. Mellor (2015) interviewed Australian students about their experiences with using SNSs for both personal and educational purposes. She found that students expressed the importance of trust when using SNSs as learning tools. Kitsantas, Dabbagh, Chirinos, and Fake (2016) surveyed 128 college students who had used SNSs for educational purposes in the United States. The authors found that though SNSs positively influenced these students' academic work, the students also reported some concerns: that SNS usage can be addictive, distracting, and/or a threat to their privacy, and that SNSs might have a negative impact on their emotional health and work completion. Regarding these points, Kim and Yoo (2016) drew attention to gender differences in the use of SNSs for education: female higher-education students in their study were more concerned about security and found it more difficult to complete their work on time. Mirabolghasemi, Iahad, and Rahim (2016) conducted an online survey consisting of 55 questions with 109 students from a public university in Malaysia. They found that SNS usage in education is not wholly positive. Those students had some significant concerns (e.g., security and a loss of creativity due to easy access to everything). Finally, Helou and Rahim (2014) found that addiction to SNSs has negatively affected the academic life of university students. Briefly, the literature suggests that students have some concerns about the use of SNSs in education that may hinder their engagement with this technology in this context. Thus, there is a need for further in-depth analysis (Kim \& Yoo, 2016; Mirabolghasemi et al., 2016).

\section{Purpose of the study}

Studies in the literature on the use of SNSs in education focus on issues such as instructors' uses of SNSs (Manca \& Ranieri, 2016), the effects of SNSs on students' academic achievement (Kirschner \& Karpinski, 2010; Sánchez et al., 2014), the nature of SNSs (Manca \& Ranieri, 2013) and professional development in lifelong learning (Ranieri, Manca, \& Fini, 2012). However, detailed analyses of students’ perspectives are less common. Eliciting students' detailed opinions about the technology used in education and involving them in these studies are of great importance, if researchers wish to identify the most effective uses of this technology (Dündar \& Akçayır, 2014; Sánchez et al., 2014). Thus, the current study was designed to conduct an in-depth investigation of the students' usage, perceptions, expectations and concerns regarding SNSs in education. The following research questions (RQ) guided the study:

- $\quad$ RQ1: How are the students using SNSs?

- RQ2: What are the students’ purposes of using SNSs?

- $\quad$ RQ3: What are the university students' perceptions of using SNSs for educational purposes?

- RQ4: What are the university students' expectations about using SNSs for educational purposes?

- $\quad$ RQ5: What are the university students' concerns about using SNSs for educational purposes?

\section{Method}

\section{The design}

Mixed method research facilitates the examination of a phenomenon within its context using diverse data sources (Creswell \& Clark, 2007). Another reason for preferring a mixed method is to increase the validity and reliability of the results (Borrego, Douglas, \& Amelink, 2009). In this study, a mixed method was used to investigate students' reactions with and thoughts concerning SNSs in education. Both qualitative and quantitative data sources were utilised.

\section{The participants}

A convenience sampling procedure was used to select a group of undergraduate students convenient to the researcher because they were students in the same university and were available and willing to participate. 
Since this is a descriptive mixed study, convenience sampling is considered an appropriate method (Fraenkel \& Wallen, 2009). Data were collected from 206 students (100 males, 106 females), aged 18-28 $(M=19.28, S D=1.60)$. All of these participants were attending a state university in Turkey (see Table 1$)$. The sample is representative in the context of students attending a state university in a developing country.

The students were recruited from three faculties (Faculty of Education, Faculty of Economics and Administrative Sciences and Faculty of Engineering) within the 12 faculties in the university; this was due to student availability to the researcher. Among the participants, 58 volunteers (31 males, 27 females) were selected to be interviewed. Semi-structured interviews were conducted with 12 students from the Department of Public Administration; eight were from the Department of Science Teacher Education; six were from the Department of Psychological Counseling and Guidance; six were from the Department of Computer Engineering; 16 were from the Department of Computer Education and Instructional Technologies; and ten were from the Department of Economics. While determining the sample sizes for the interviews, I attempted to maintain a nearly equal sample distribution as that of students from across these departments. For example, the percentage of participating students from the Science Teacher Education Department is $18 \%$ and the percentage of interviewees from that department is $14 \%$.

Table 1

Demographics of the participants

\begin{tabular}{llc}
\hline Department & Gender & $\begin{array}{c}\text { Number of participants } \\
\text { surveyed/interviewed }\end{array}$ \\
\hline Public Administration & Male & $42 / 10$ \\
Science Teacher Education & Female & $25 / 2$ \\
Psychological Counseling and Guidance & Male & $10 / 2$ \\
Computer Engineering & Female & $27 / 6$ \\
& Male & $6 / 2$ \\
Computer Education and Instructional Technologies & Female & $24 / 4$ \\
& Male & $21 / 5$ \\
Economics & Female & $9 / 1$ \\
& Male & $12 / 7$ \\
\hline
\end{tabular}

\section{The data collection tools}

As a data collection instrument, the social networking use survey developed by Lim and Richardson (2016) was used. The social networking use survey consists of three sub-categories (see Table 2). This paper-andpencil-based survey was distributed to all of the students by the researcher and a colleague of the researcher.

Table 2

Information about SNS survey questions

\begin{tabular}{ll}
\hline Sub-categories & Descriptions \\
\hline (1) Q1-Q4 (Demographic items) & $\begin{array}{l}\text { The first section of the survey collected demographic } \\
\text { (department, grade, age, gender) information. }\end{array}$ \\
$\begin{array}{ll}\text { (2) Q5-Q8 (Questions for general } \\
\text { information about the use of }\end{array}$ & $\begin{array}{l}\text { General information questions about the use of SNSs, } \\
\text { including ownership of social network accounts, types of } \\
\text { SNSs being used, degree of SNS experience and purposes of } \\
\text { using SNSs }\end{array}$ \\
& $\begin{array}{l}\text { Eleven questions examining the students' perceptions of } \\
\text { using SNSs for educational purposes. Cronbach’s alpha was } \\
\text { (3) Q9-Q19 (Items on a 5-point } \\
\text { disagree to 5 strongly agree) }\end{array}$ \\
\hline
\end{tabular}

To better understand the students' perceptions, expectations and concerns regarding using SNSs for educational purposes, it was critical to seek their opinions. For this purpose, face-to-face semi-structured interviews were conducted. 
The interviews were conducted on a one-to-one basis with one student and the researcher each time. The students' opinions expressed during the interviews were audio-recorded and also hand-recorded on an interview form by the researcher. Each interview lasted 8-15 minutes. The interviewing process took approximately nine weeks to complete (during the Fall semester of 2015-2016).

\section{The data analysis}

Descriptive statistical analyses were performed on the quantitative data using IBM SPSS 21 software. Frequency, percentage, mean and standard deviation were calculated, to support or counter the qualitative data.

The qualitative data collected from the interviews were analysed with the quantitative content analysis method. An open coding process was employed. No coding scheme (pre-developed form or template) was used. An analytical three-stage process established by Emerson, Fretz, and Shaw (1995) was utilised by the researcher to analyse the data from the interviews.

First, all the data were coded. The codes were designed to be free of any intended relevance either to established concepts in a particular discipline or to a primary theoretical focus. According to Emerson et al. (1995), a code is "a word or short phrase that captures and signals what is going on in a piece of data in a way that links it to some more general analysis issue” (p .146).

Second, themes were identified. As Rossman and Rallis (2003) explained, the difference between themes and codes is that a code is an explicit word or phrase describing a segment of data, while a theme is a phrase or sentence that describes more subtle or tacit processes. To name the themes, the most descriptive wording was determined. Dey (2005) stated that "as far as possible, categories (themes) reflecting the same dimension of the analysis should not overlap unduly” (p. 117). Thus, when generating the themes, I considered the connections between the codes and avoided needless overlaps. Third, the coded responses were rearranged according to the themes. An example of the data analysis process relating to two students' comments about their purposes of using SNSs is illustrated in Figure 1.

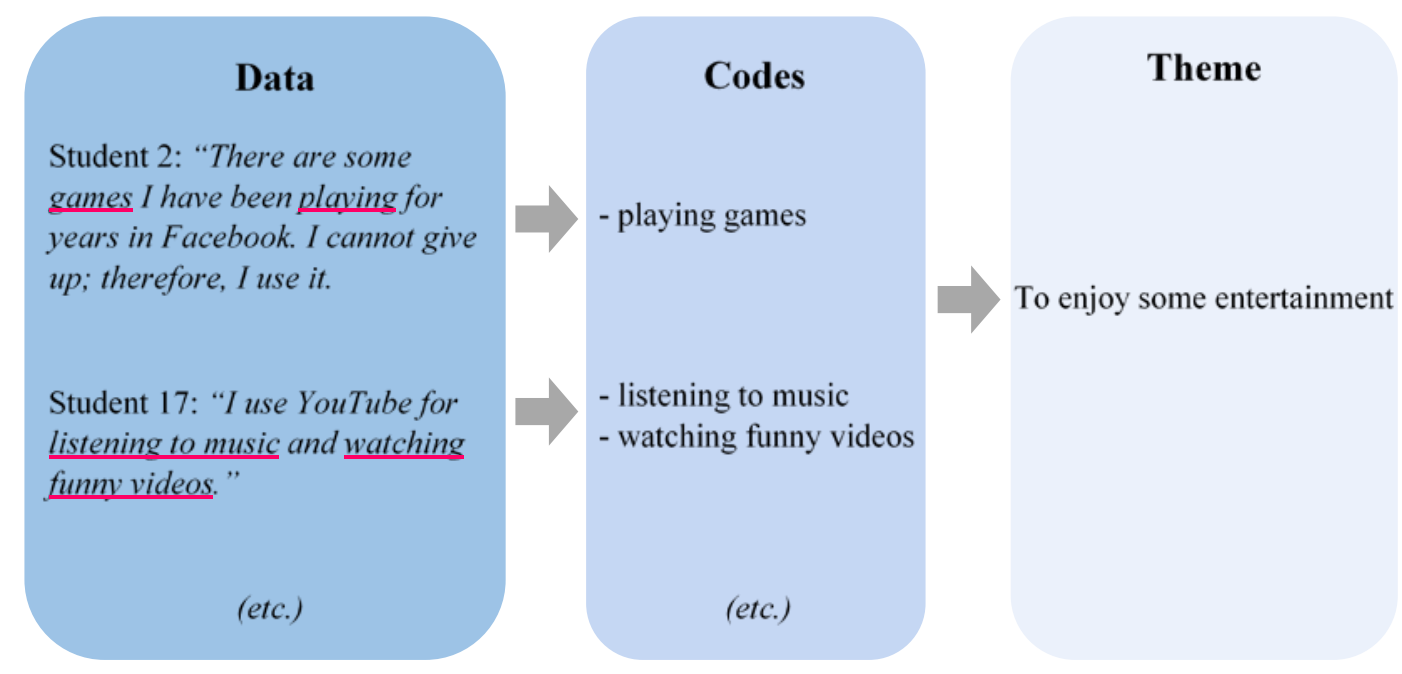

Figure 1. Illustrative example of the data analysis process (two students' purpose statements on SNS use)

While reporting the findings, frequencies were used. According to Yıldırım and Şimşek (2005), the expression of qualitative data with numbers provides increased reliability and enhanced objectivity, and it enables comparisons to be made between themes.

According to Patton (2002), reliability and validity in qualitative studies are very important and determine the soundness, trustworthiness and credibility of any qualitative research. To ensure the reliability of the coding process, 15 (26\%) interviews were picked randomly and analysed independently and separately by the researcher and an external coder who is a faculty member and familiar with the content. As is typical in the literature, Cohen's kappa was selected to check the inter-coder reliability (Strijbos, Martens, Prins, \& 
Jochems, 2006). As a result of the calculation of Cohen's kappa, the Kappa for inter-coder reliability was found to be .87 . Viera and Garrett (2005) maintain that any value between .81 and .99 represents an almost perfect agreement. After validating the coding scheme, the researcher independently coded the rest of the interview responses. As Oliver-Hoyo and Allen (2006) suggested, the validity was established through triangulation by using multiple data sources, including surveys and interviews.

\section{Results}

\section{RQ1: How are the students using SNSs?}

To examine the SNS usage of the students, their self-provided information was analysed with the descriptive statistics method (see Table 3). In this way, general information about the students' uses of SNS were obtained.

Table 3

Students' uses of SNSs

\begin{tabular}{lcc}
\hline & Number of respondents & Percentage of respondents \\
\hline Account owner of any SNS & \multicolumn{2}{c}{} \\
$\quad$ Yes & 198 & $96 \%$ \\
No & 8 & $4 \%$ \\
Experience (Year/s) & 10 & $5 \%$ \\
$0-1$ & 26 & $13 \%$ \\
$1-3$ & 71 & $34 \%$ \\
$4-5$ & 99 & $48 \%$ \\
More than 6 years & & \\
SNS used & 164 & $80 \%$ \\
YouTube & 159 & $77 \%$ \\
Facebook & 94 & $46 \%$ \\
Twitter & 72 & $35 \%$ \\
Instagram & 23 & $11 \%$ \\
Other & & \\
\hline
\end{tabular}

In Table 3, note that only a few students (4\%) did not possess a SNS account of some kind. The students' overall SNS experience is generally high, with only 10 students possessing little experience. The students most widely used YouTube (80\%), followed by Facebook (77\%). Moreover, a majority of the students used more than one SNS service.

\section{RQ2: What are the students' purposes of using SNSs?}

The data obtained from the questionnaire reveals that the students most frequently used SNSs to communicate with their friends (see Table 4). The second most frequent use of SNSs by the students was to obtain and share new information. According to the findings, there is a big difference between the obtaining and the sharing of information. This shows that the students used SNSs to acquire information more often than to share it.

Table 4

Purposes of the students' SNS uses (quantitative results)

\begin{tabular}{lcc}
\hline Purpose & $\begin{array}{c}\text { Number } \\
\text { of respondents }\end{array}$ & $\begin{array}{c}\text { Percentage of } \\
\text { respondents }\end{array}$ \\
\hline To keep in touch with friends & 143 & $69 \%$ \\
To obtain some new information & 127 & $62 \%$ \\
To share some information or materials & 69 & $33 \%$ \\
To connect with people I have lost touch with & 63 & $31 \%$ \\
To let others know what is happening in my life & 54 & $26 \%$ \\
To do career networking & 40 & $19 \%$ \\
\hline
\end{tabular}


The findings from the interviews with the students provided additional information about the students' SNS usage purposes. As can be seen in Table 5, the students again used SNSs for communication purposes. For example, one student stated that she used SNSs to communicate with her parents because the SNS services are free of charge.

In the interviews, purposes which did not appear in the questionnaire items (e.g., to follow educational groups) were also found. Nearly half of the students (48\%) stated that they used SNSs to share course materials with their friends. Moreover, they used them to access extra materials by following education groups which prepare students for exams (e.g., officer selection exam, English exam), to contact experts and to watch lecture videos. This shows that the students also used SNSs for educational purposes.

Table 5

Purposes of the students' SNS uses (qualitative results)

\begin{tabular}{|c|c|c|}
\hline Themes & $\begin{array}{l}\text { Number of } \\
\text { participants } \\
\text { who } \\
\text { commented } \\
\text { (Percentage) }\end{array}$ & Example quotations \\
\hline $\begin{array}{l}\text { To keep in touch with } \\
\text { friends through SNSs }\end{array}$ & $41(71 \%)$ & $\begin{array}{l}\text { "My only purpose for use is to communicate with my } \\
\text { family and friends." }\end{array}$ \\
\hline $\begin{array}{l}\text { To share some educational } \\
\text { information or materials }\end{array}$ & $28(48 \%)$ & $\begin{array}{l}\text { "In our class’s Facebook group, materials are } \\
\text { continuously shared among friends. I use it for this } \\
\text { purpose.” }\end{array}$ \\
\hline $\begin{array}{l}\text { To enjoy some } \\
\text { entertainment (playing } \\
\text { games, listening to music, } \\
\text { watching videos, etc.) }\end{array}$ & 27 (47\%) & $\begin{array}{l}\text { "There are some games I have been playing for years } \\
\text { in Facebook. I cannot give up; therefore, I use it." }\end{array}$ \\
\hline $\begin{array}{l}\text { To follow educational } \\
\text { groups }\end{array}$ & $16(28 \%)$ & $\begin{array}{l}\text { "There are YouTube groups to prepare people for } \\
\text { English exams. I watch sample question solutions } \\
\text { and can ask questions.” }\end{array}$ \\
\hline To obtain some news & $16(28 \%)$ & $\begin{array}{l}\text { "I use them to follow news pages. For example, in } \\
\text { Twitter you can learn fast about any news." }\end{array}$ \\
\hline $\begin{array}{l}\text { To share pictures or } \\
\text { videos }\end{array}$ & $5(9 \%)$ & "I share the photos I have taken." \\
\hline $\begin{array}{l}\text { To follow personal hobby } \\
\text { groups’ pages }\end{array}$ & $5(9 \%)$ & $\begin{array}{l}\text { "I use them to get information about my own } \\
\text { hobbies. I am interested in model planes, and I can } \\
\text { get useful information about them." }\end{array}$ \\
\hline To archive documents & $1(2 \%)$ & $\begin{array}{l}\text { "I store my pictures, documents. I can hide my } \\
\text { information and data more easily and safely." }\end{array}$ \\
\hline
\end{tabular}

\section{RQ3: What are the university students' perceptions of using SNSs for educational purposes?}

The students' perceptions of the educational uses of SNSs are shown in Table 6. Based on the mean scores, the students agreed that using SNSs for educational purposes would be convenient $(M=3.97)$ and that they could be used to share class materials $(M=3.70)$ and to support face-to-face learning $(M=3.64)$. In the survey, two negative perspective items have lower means: "I feel that my privacy would be invaded if SNS and my courses overlapped" $(M=2.50)$ and "I don't care one way or the other about SNS being used for educational purposes” $(M=2.46)$. Even if students felt positively about using SNS for educational purposes, the third lowest item score, "I would feel more comfortable using SNS as a discussion tool in place of traditional course discussion” ( $M=2.76)$, indicates that they don't feel comfortable about replacing traditional techniques with SNSs. 
Table 6

Students' perceptions of the educational uses of SNSs

\begin{tabular}{|c|c|c|c|c|c|c|}
\hline \multirow[t]{2}{*}{ Question } & \multirow{2}{*}{$\begin{array}{l}\begin{array}{l}\text { Strongly } \\
\text { disagree }\end{array} \\
n(\%)\end{array}$} & Disagree & \multirow{2}{*}{$\begin{array}{l}\text { Neither } \\
\text { agree/ } \\
\text { disagree }\end{array}$} & \multirow{2}{*}{$\begin{array}{l}\text { Agree } \\
n(\%) \\
\end{array}$} & \multirow{2}{*}{$\begin{array}{l}\begin{array}{l}\text { Strongly } \\
\text { agree }\end{array} \\
n(\%) \\
\end{array}$} & \multirow[t]{2}{*}{$M(S D)$} \\
\hline & & $n(\%)$ & & & & \\
\hline $\begin{array}{l}\text { Using SNSs for educational } \\
\text { purposes would be } \\
\text { convenient }\end{array}$ & $23(11 \%)$ & $9(4 \%)$ & $17(8 \%)$ & 60 (29\%) & 97 (47\%) & $\begin{array}{l}3.97 \\
(1.32)\end{array}$ \\
\hline $\begin{array}{l}\text { SNSs could be used to } \\
\text { support face-to-face learning }\end{array}$ & $23(11 \%)$ & 25 (12\%) & 21 (10\%) & 72 (35\%) & 65 (32\%) & $\begin{array}{l}3.64 \\
(1.33)\end{array}$ \\
\hline $\begin{array}{l}\text { Using SNSs for class could } \\
\text { increase motivation for } \\
\text { learning }\end{array}$ & 20 (10\%) & 23 (11\%) & 45 (22\%) & 60 (29\%) & 58 (28\%) & $\begin{array}{l}3.55 \\
(1.27)\end{array}$ \\
\hline $\begin{array}{l}\text { Using SNSs for class could } \\
\text { make me feel more } \\
\text { connected to my learning } \\
\text { community }\end{array}$ & 32 (16\%) & 45 (22\%) & 56 (27\%) & 45 (22\%) & 28 (14\%) & $\begin{array}{l}2.96 \\
(1.27)\end{array}$ \\
\hline $\begin{array}{l}\text { I would feel more } \\
\text { comfortable using SNSs as a } \\
\text { discussion tool in place of } \\
\text { traditional course discussion }\end{array}$ & 44 (21\%) & 55 (27\%) & 48 (23\%) & $24(12 \%)$ & 35 (17\%) & $\begin{array}{l}2.76 \\
(1.36)\end{array}$ \\
\hline $\begin{array}{l}\text { SNSs could be used } \\
\text { effectively to share class } \\
\text { materials }\end{array}$ & $14(7 \%)$ & 21 (10\%) & 34 (17\%) & 80 (39\%) & 57 (28\%) & $\begin{array}{l}3.70 \\
(1.17)\end{array}$ \\
\hline $\begin{array}{l}\text { Using SNSs as an } \\
\text { educational platform could } \\
\text { facilitate better rapport with } \\
\text { peers }\end{array}$ & 22 (11\%) & 40 (19\%) & 60 (29\%) & 51 (25\%) & 33 (16\%) & $\begin{array}{l}3.16 \\
(1.22)\end{array}$ \\
\hline $\begin{array}{l}\text { SNSs could be an effective } \\
\text { way to collaborate with } \\
\text { peers }\end{array}$ & 24 (12\%) & 27 (13\%) & 45 (22\%) & 86 (42\%) & $24(12 \%)$ & $\begin{array}{l}3.29 \\
(1.18)\end{array}$ \\
\hline $\begin{array}{l}\text { SNSs could be an effective } \\
\text { way to communicate with } \\
\text { peers }\end{array}$ & 21 (10\%) & 25 (12\%) & 38 (18\%) & 81 (39\%) & 41 (20\%) & $\begin{array}{l}3.47 \\
(1.23)\end{array}$ \\
\hline $\begin{array}{l}\text { I feel that my privacy would } \\
\text { be invaded if SNSs and my } \\
\text { courses overlapped }\end{array}$ & 49 (24\%) & 67 (33\%) & 48 (23\%) & 21 (10\%) & 21 (10\%) & $\begin{array}{l}2.50 \\
(1.24)\end{array}$ \\
\hline $\begin{array}{l}\text { I don't care one way or the } \\
\text { other about SNSs being used } \\
\text { for educational purposes }\end{array}$ & 71 (34\%) & 47 (23\%) & 39 (19\%) & 21 (10\%) & 28 (14\%) & $\begin{array}{l}2.46 \\
(1.40)\end{array}$ \\
\hline
\end{tabular}

\section{RQ4: What are the university students' expectations about using SNSs for educational purposes?}

The biggest expectation of the students concerning the educational uses of SNSs is the instructors sharing course materials and supplementary materials over SNSs (see Table 7). Another expectation is the videorecording of lessons and the sharing of these recordings over SNSs (e.g., YouTube) (62\%). More than half of the students participating in the interviews (53\%) expected to communicate with their instructors through SNSs. 
Table 7

Students' expectations about using SNSs for educational purposes

\begin{tabular}{|c|c|c|}
\hline Themes & $\begin{array}{l}\text { Number of } \\
\text { participants who } \\
\text { commented } \\
\text { (Percentage) } \\
\end{array}$ & Example quotations \\
\hline $\begin{array}{l}\text { Instructors sharing the course } \\
\text { materials (e.g., a course book, } \\
\text { slides, supplementary documents) }\end{array}$ & $39(67 \%)$ & $\begin{array}{l}\text { "I expect the instructor to share the materials } \\
\text { he/she uses in the class in our Facebook } \\
\text { group." }\end{array}$ \\
\hline $\begin{array}{l}\text { Video-recording of classes and } \\
\text { sharing these recordings through } \\
\text { SNSs }\end{array}$ & $36(62 \%)$ & $\begin{array}{l}\text { "I want my instructors to video-record their } \\
\text { lessons and share them through SNS. Thus, } \\
\text { we can revise any course we want." }\end{array}$ \\
\hline $\begin{array}{l}\text { Communicating with instructors } \\
\text { through SNSs }\end{array}$ & 31 (53\%) & $\begin{array}{l}\text { "I want to ask my instructors questions } \\
\text { about the things we have not understood and } \\
\text { get immediate responses." }\end{array}$ \\
\hline $\begin{array}{l}\text { Conducting some of the lessons } \\
\text { online using SNSs }\end{array}$ & $16(28 \%)$ & $\begin{array}{l}\text { "I sometime want to our lessons to be } \\
\text { presented over the Internet. For instance, } \\
\text { live lecturing or revision of the lesson can be } \\
\text { presented through YouTube." }\end{array}$ \\
\hline $\begin{array}{l}\text { Announcements made through } \\
\text { SNSs }\end{array}$ & $10(17 \%)$ & $\begin{array}{l}\text { "If the announcements about the courses } \\
\text { were made through SNS, it would be better } \\
\text { for us. They can be heard faster." }\end{array}$ \\
\hline $\begin{array}{l}\text { Submission of assignments using } \\
\text { SNSs }\end{array}$ & $3(5 \%)$ & $\begin{array}{l}\text { "Submission of assignments takes time } \\
\text { sometimes. It should be allowed that they be } \\
\text { submitted using SNS." }\end{array}$ \\
\hline $\begin{array}{l}\text { Construction of educational } \\
\text { activities }\end{array}$ & $1(2 \%)$ & $\begin{array}{l}\text { "The instructor may construct educational } \\
\text { activities on Facebook and then invite } \\
\text { students." }\end{array}$ \\
\hline
\end{tabular}

When investigating the educational uses of SNSs, most researchers select one based upon its general popularity among students (Manca \& Ranieri, 2013). However, it is not clear whether a particular SNS's popularity relates to students' expectation to use the SNS for education; if given that criteria, they might select another SNS. Therefore, during the interviews the students were asked to state which SNS they would most expect to be used in education (see Figure 2). YouTube (57\%) took first place, followed by Facebook (29\%). The students' expectation that Twitter would be used for educational purposes was low (7\%).

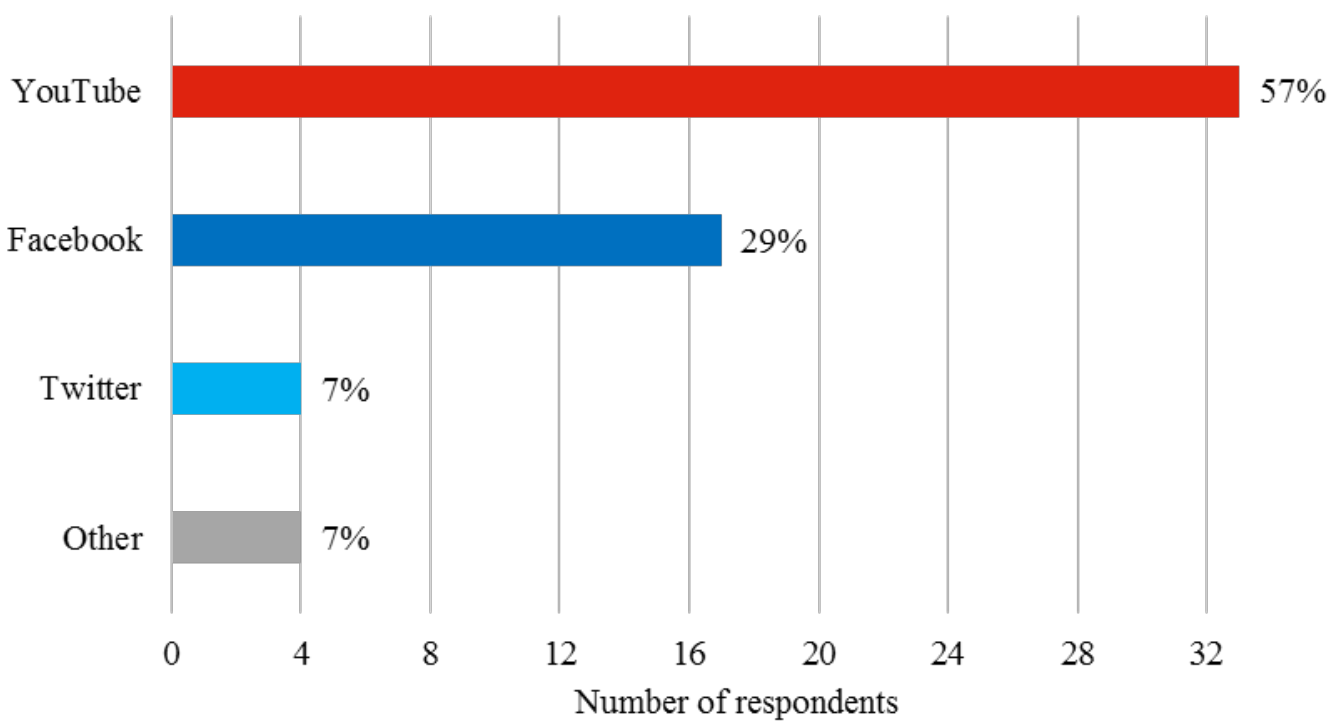

Figure 2. SNS expected to be used in education, according to students 


\section{RQ5: What are the university students' concerns about using SNSs for educational purposes?}

The biggest concern of the students (see Table 8) about the use of SNSs in education is the instructors seeing their personal posts (40\%). They thought that the instructor might misunderstand the messages that they shared among themselves, and that this might lead to some problems. Other concerns are that when SNSs are used for educational purposes, the students might stray from the subject (12\%), they might become addicted $(10 \%)$ or they might waste their time $(10 \%)$. Some of the students who took part in the interviews (26\%) stated that they do not have any concerns about the educational uses of SNSs.

Table 8

Students' concerns about using SNSs for educational purposes

\begin{tabular}{|c|c|c|}
\hline Themes & $\begin{array}{l}\text { Number of } \\
\text { participants who } \\
\text { commented } \\
\text { (Percentage) }\end{array}$ & Example quotations \\
\hline $\begin{array}{l}\text { The instructor will be able to } \\
\text { see my posts (e.g., comments, } \\
\text { wall posts) }\end{array}$ & $23(40 \%)$ & $\begin{array}{l}\text { "The instructor may see and misunderstand the } \\
\text { comments we have written about him/her." }\end{array}$ \\
\hline Straying from the subject & $7(12 \%)$ & $\begin{array}{l}\text { "While using SNS, my friends may start } \\
\text { conversations that are off the subject, and thus I } \\
\text { may wander from the subject." }\end{array}$ \\
\hline Threat of addiction & $6(10 \%)$ & $\begin{array}{l}\text { "The use of SNS may cause an addiction for } \\
\text { me." }\end{array}$ \\
\hline Threat of wasting time & $6(10 \%)$ & $\begin{array}{l}\text { "The use of SNS may result in a waste of my } \\
\text { time. It would be better for me to go to the } \\
\text { library." }\end{array}$ \\
\hline $\begin{array}{l}\text { It curbs the development of my } \\
\text { research ability }\end{array}$ & $5(9 \%)$ & $\begin{array}{l}\text { "The use of SNS may make the students lazy. I } \\
\text { do not feel the need to have access to } \\
\text { resources." }\end{array}$ \\
\hline $\begin{array}{l}\text { Threats of clickjacking and } \\
\text { harmful files }\end{array}$ & $4(7 \%)$ & $\begin{array}{l}\text { "Infected files can rapidly disseminate over } \\
\text { SNS.” }\end{array}$ \\
\hline SNS posts are unreliable & $3(5 \%)$ & "I cannot rely on information shared over SNS." \\
\hline
\end{tabular}

\section{Discussion and conclusion}

The results indicate that these university students were very experienced with SNSs, which is consistent with previous findings (Lim \& Richardson, 2016; Smith, 2014). One surprising result is that YouTube was selected as the most widely used SNS (80\%), despite the fact that Facebook was thought to be the most popular and widely used by students (Akçayır \& Akçayır, 2016). In other words, while many researchers (e.g., Thelwall \& Kousha, 2014) have found that Facebook is the most used SNS among higher education students, the results of this study contrast with previous research, showing that YouTube is the most used SNS, followed by Facebook (77\%).

This study indicates that building and maintaining social relationships are the students' dominant purposes of using SNSs (69\%). Students also use SNSs to obtain (62\%) and share (33\%) information and materials. A similar result was reported by Lim and Richardson (2016), who found that forming social relationships is the dominant purpose of using SNSs, but that another purpose is to obtain and share information and materials. However, they did not clarify in their study whether the purpose behind obtaining and sharing information and materials was educational or not. In the current study, I found that students obtain and share information and materials using SNSs specifically for educational purposes. Additionally, another purpose of using SNSs for education is to follow educational groups (e.g., YouTube channels). This result agrees with the results of Eteokleous, Ktoridou, Stavrides, and Michaelidis (2012), who found that a large percentage of students follow educational groups within SNSs for reasons such as exchanging information, meeting new people with similar interests and keeping up with topics of interest.

The current study also shows that students' perceptions of the educational uses of SNSs are generally positive, and that they seemed open to the use of SNSs in education. One potential explanation for the 
students' positive perceptions is their familiarity and experience with SNSs. But, nearly half of the students (48\%) did not feel more comfortable using an SNSs as a discussion tool in place of traditional course discussion. This result corresponds with the findings of Lim and Richardson (2016), who reported that students do not feel comfortable going so far as to disrupt or replace traditional course techniques with SNS usage.

Regarding the students' expectations about the use of SNSs for educational purposes, they reported that they expect their instructors to use SNSs; and if they are using SNSs, the students also expect them to use the technology actively. The students expect their instructors to share materials (67\%), produce digital materials (62\%) (e.g., video recordings), communicate with their students (53\%), offer their lessons through SNSs (28\%) and accept the submission of assignments through SNSs (5\%). Each of these functions requires that instructors use SNSs actively. Most of the students expected instructors to share course materials through SNSs (67\%) and also some lessons (28\%). These expectations resemble some of the basic requirements of blended learning (Bonk \& Graham, 2012); therefore, we can conclude that students have an expectation for blended learning. Moreover, though researchers consider the use of Facebook suitable for educational purposes (Akçayır \& Akçayır, 2016), in the current study relatively few students (29\%) expected the use of Facebook for educational purposes. The main reasons that researchers prefer Facebook for educational purposes are its popularity and their belief that it can satisfy students' expectations (Manca \& Ranieri, 2013). However, the students in this study reported that they expect to use YouTube most for educational purposes (57\%). This raises the question as to whether researchers should choose an SNS based on students' explicit expectations or the unspecific popularity of that SNS among students.

Another important finding related to the students' expectations is that they wanted course materials (e.g., course books, slides, supplementary documents) to be shared by their instructors through the SNS in digital form (67\%). This result is consistent with the findings of Akçayır, Akçayır, Pektaş, and Ocak (2016), who reported that university students prefer digital materials to traditional materials. A possible explanation for this expectation is that these students possess the characteristics of “digital natives." To digital natives, visuals, pictures and graphics are more attractive than a traditional written text (Prensky, 2001). The reason for the students' desire to engage in spontaneous communications with their instructors may be related to their digital native characteristics as well. Digital natives tend to use the quickest way to meet their needs and to satisfy their desires (Teo, Kabakçı Yurdakul, \& Ursavaş, 2014).

The current study reveals that there are some factors which concern the students regarding the use of SNSs for education. The main factor is their privacy concerns. The students are worried about their instructors being able to see their personal comments (40\%) and possibly misunderstanding them. This finding is consistent with previous research, which reports that students' privacy concerns may hinder SNS use in education (Feng \& Xie, 2014).

In conclusion, it is clear that students have several expectations which require an instructor's active participation in SNS activities, and that they also have some concerns that should not be ignored. If we want to use SNSs in education effectively, we need to consider the students' perspectives.

Regarding the limitations of this study, first, the data collection was limited to students from only one state university. Second, the convenient sampling method used in this study may raise questions about generalisability and also might compromise the representativeness of the sample to the overall population (Creswell, 2009). Therefore, researchers may want to replicate this study with more diverse samples in terms of culture, geographic location, university.

\section{Implications}

In this section, some implications for practice, policy and further research are suggested, based upon our results. First, because the students' perceptions of the educational uses of SNSs were generally positive, instructors may wish to use SNSs in their instructional designs, to enhance student' learning experiences. This can be done by using an SNS as either an learning management system (Wang et al., 2012), a collaboration tool (Lampe, Wohn, Vitak, Ellison, \& Wash, 2011), a discussion platform (Lin, Hou, Wang, \& Chang, 2013), a tool for promoting a community of practice (Hung \& Yuen, 2010) and/or a tool for fostering engagement (Junco et al., 2011) and interaction (Beldarrain, 2006). Instructors can use also SNSs to support many instructional approaches, such as formal learning (Lockyer \& Patterson, 2008), informal 
learning (Madge et al., 2009), mobile learning (Pachler, Ranieri, Manca, \& Cook, 2012) and blended learning (McCarthy, 2010).

Second, while designing instruction, students' concerns (e.g., regarding privacy when using SNSs) should be considered. For example, since the biggest concern of students is that their instructors can see students' personal posts, instructors may allow students to open two SNS accounts - one for educational uses and the other for personal uses. If/when these concerns are adequately addressed, students may be more willing to use SNSs for education, just as they currently use them in everyday life.

Third, institutions should provide specialised and tailored training (e.g., examples of good practice, creative teaching practices, training to improve digital skills) to instructors to teach them effective ways to use SNSs for educational purposes. As is indicated in the literature (Manca \& Ranieri, 2015), the concrete use of tools during training can increase self-efficiency, confidence and the capacity to more greatly benefit from digital technologies used in education. Therefore, educational institutions should not only encourage and support instructors (e.g., technically and pedagogically) to use SNSs for educational purposes, but also to more closely match their practices with the expectations of students as defined in this study.

Fourth, this study provides a basis for pursuing several important research directions. For instance, using SNSs in accordance with students' expectations might not guarantee that sufficient learning outcomes will be met. Further research is needed to determine how students' expectations regarding SNS use in education relate to positive learning outcomes. This study also indicates that students expect instructors to use SNSs actively. Therefore, additional research is needed to identify and examine in greater depth instructors' opinions, expectations, and concerns regarding educational uses of SNSs.

\section{References}

Ajjan, H., \& Hartshorne, R. (2008). Investigating faculty decisions to adopt Web 2.0 technologies: Theory and empirical tests. The Internet and Higher Education, 11(2), 71-80. doi:10.1016/j.iheduc.2008.05.002

Akçayır, G., \& Akçayır, M. (2016). Research trends in social network sites’ educational use: a review of publications in all SSCI journals to 2015. Review of Education, 4(3), 293-319. doi:10.1002/rev3.3075

Akçayır, M., Akçayır, G., Pektaş, H. M., \& Ocak, M. A. (2016). Augmented reality in science laboratories: The effects of augmented reality on university students' laboratory skills and attitudes toward science laboratories. Computers in Human Behavior, 57, 334-342. doi:10.1016/j.chb.2015.12.054

Arnold, N., \& Paulus, T. (2010). Using a social networking site for experiential learning: Appropriating, lurking, modeling and community building. The Internet and Higher Education, 13(4), 188-196. doi:10.1016/j.iheduc.2010.04.002

Aydin, S. (2014). Foreign language learners' interactions with their teachers on Facebook. System, 42, 155-163. doi:10.1016/j.system.2013.12.001

Backer, E. (2010). Using smartphones and Facebook in a major assessment: The student experience. $e$ Journal of Business Education \& Scholarship of Teaching, 4(1), 19-31. Retrieved from http://www.ejbest.org/upload/eJBEST_Backer_2010_4(1).pdf

Baran, B. (2010). Facebook as a formal instructional environment. British Journal of Educational Technology, 41(6), E146-E149. doi:10.1111/j.1467-8535.2010.01115.x

Bartlett-Bragg, A. (2006). Reflections on pedagogy: Reframing practice to foster informal learning with social software. Retrieved from http://citeseerx.ist.psu.edu/viewdoc/download?doi=10.1.1.472.2265\&rep=rep1\&type=pdf

Beldarrain, Y. (2006). Distance education trends: Integrating new technologies to foster student interaction and collaboration. Distance Education, 27(2), 139-153. doi:10.1080/01587910600789498

Bonk, C. J., \& Graham, C. R. (2012). The handbook of blended learning: Global perspectives, local designs. San Francisco, CA: John Wiley \& Sons.

Borrego, M., Douglas, E. P., \& Amelink, C. T. (2009). Quantitative, qualitative, and mixed research methods in engineering education. Journal of Engineering Education, 98(1), 53-66. doi:10.1002/j.2168-830.2009.tb01005.x

Boyd, D. M., \& Ellison, N. B. (2008). Social network sites: Definition, history, and scholarship. Journal of Computer-Mediated Communication, 13, 210-230. doi:10.1111/j.1083-6101.2007.00393.x 
Callaghan, N., \& Bower, M. (2012). Learning through social networking sites-the critical role of the teacher. Educational Media International, 49(1), 1-17. doi:10.1080/09523987.2012.662621

Casey, G. (2013). Interdisciplinary literacy through social media in the mathematics classroom: An action research study. Journal of Adolescent \& Adult Literacy, 57(1), 60-71. doi:10.1002/jaal.216

Creswell, J. W. (2009). Research design: Qualitative, quantitative, and mixed methods approaches. Thousand Oaks, CA: Sage.

Creswell, J. W., \& Clark, V. L. P. (2007). Designing and conducting mixed methods research. Thousand Oaks, CA: Sage.

Davies, I., \& Sant, E. (2014). Perceptions of students and teachers in England about howsocial media are used (and how they could be used) in schools and elsewhere. In B. D. Loader, A. Vromen, \& M. A. Xenos (Eds.), The networked young citizen: Social media, political participation and civic engagement (pp. 131-157). New York, NY: Routledge.

Dey, I. (2005). Qualitative data analysis: A user-friendly guide for social scientists. New York, NY: Routledge.

Dowdall, C. (2009). Impressions, improvisations and compositions: Reframing children's text production in social network sites. Literacy, 43(2), 91-99. doi:10.1111/j.1741-4369.2009.00521.x

Dündar, H., \& Akçayır, M. (2014). Implementing tablet PCs in schools: Students' attitudes and opinions. Computers in Human Behavior, 32, 40-46. doi:10.1016/j.chb.2013.11.020

Ebner, M., Lienhardt, C., Rohs, M., \& Meyer, I. (2010). Microblogs in higher education - A chance to facilitate informal and process-oriented learning? Computers \& Education, 55(1), 92-100. doi:10.1016/j.compedu.2009.12.006

Emerson, R. M., Fretz, R. I., \& Shaw, L. L. (1995). Writing ethnographic fieldnotes. Chicago, IL: The University of Chicago Press.

Eteokleous, N., Ktoridou, D., Stavrides, I., \& Michaelidis, M. (2012). Facebook - A social networking tool for educational purposes: Developing special interest groups. In Proceedings of the International Conference on Information Communication Technologies in Education (ICICTE 2012) (pp. 363-375). Retrieved from http://www.icicte.org/Proceedings2012/Papers/09-2-Eteokleous.pdf

Feng, Y., \& Xie, W. (2014). Teens’ concern for privacy when using social networking sites: An analysis of socialization agents and relationships with privacy-protecting behaviors. Computers in Human Behavior, 33, 153-162. doi:10.1016/j.chb.2014.01.009

Fewkes, A. M., \& McCabe, M. (2012). Facebook: Learning tool or distraction? Journal of Digital Learning in Teacher Education, 28(3), 92-98. doi:10.1080/21532974.2012.10784686

Fox, B., \& Varadarajan, R. (2011). Technology in pharmacy education: Use of Twitter to encourage interaction in a multi-campus pharmacy management course. American Journal of Pharmaceutical Education, 75(5), 1-9. doi:10.5688/ajpe75588

Fraenkel, J., \& Wallen, N. (2009). How to design and evaluate research in education. New York, NY: McGraw-Hill.

Gettman, H. J., \& Cortijo, V. (2015). “Leave me and my Facebook alone!” Understanding college students’ relationship with Facebook and its use for academic purposes. International Journal for the Scholarship of Teaching and Learning, 9(1), 1-16. doi:10.20429/ijsotl.2015.090108

Greenhow, C., \& Robelia, B. (2009). Old communication, new literacies: Social network sites as social learning resources. Journal of Computer-Mediated Communication, 14(4), 1130-1161. doi:10.1111/j.1083-6101.2009.01484.X

Greenhow, C., Robelia, B., \& Hughes, J. E. (2009). Learning, teaching, and scholarship in a digital age: Web 2.0 and classroom research: What path should we take now? Educational Researcher, 38(4), 246-259. doi:10.3102/0013189x09336671

Helou, A. M., \& Rahim, N. Z. (2014). The influence of social networking sites on students' academic performance in Malaysia. International Journal of Electronic Commerce Studies, 5(2), 247-254. doi:10.7903/ijecs.1114

Hung, H.-T., \& Yuen, S. C.-Y. (2010). Educational use of social networking technology in higher education. Teaching in Higher Education, 15(6), 703-714. doi:10.1080/13562517.2010.507307

Issa, T., Isaias, P., \& Kommers, P. (2016). Social networking. In T. Issa, P. Isaias, \& P. Kommers (Eds.), Social networking and education: Global perspectives (pp. 3-13). Cham: Springer.

Junco, R. (2012). The relationship between frequency of Facebook use, participation in Facebook activities, and student engagement. Computers \& Education, 58(1), 162-171. doi:10.1016/j.compedu.2011.08.004 
Junco, R., Heiberger, G., \& Loken, E. (2011). The effect of Twitter on college student engagement and grades. Journal of Computer Assisted Learning, 27(2), 119-132. doi:10.1111/j.13652729.2010.00387.x

Kalin, J. (2012). Doing what comes naturally? Student perceptions and use of collaborative technologies. International Journal for the Scholarship of Teaching and Learning, 6(1), 1-21. doi:10.20429/ijsotl.2012.060110

Khan, M. L., Wohn, D. Y., \& Ellison, N. B. (2014). Actual friends matter: An internet skills perspective on teens' informal academic collaboration on Facebook. Computers \& Education, 79, 138-147. doi:10.1016/j.compedu.2014.08.001

Kim, S., \& Yoo, S. J. (2016). Age and gender differences in social networking: Effects on South Korean students in higher education. In T. Issa, P. Isaias, \& P. Kommers (Eds.), Social networking and education: Global perspectives (pp. 69-82). Cham: Springer.

Kirschner, P. A., \& Karpinski, A. C. (2010). Facebook® and academic performance. Computers in Human Behavior, 26(6), 1237-1245. doi:10.1016/j.chb.2010.03.024

Kitsantas, A., Dabbagh, N., Chirinos, D. S., \& Fake, H. (2016). College students’ perceptions of positive and negative effects of social networking. In T. Issa, P. Isaias, \& P. Kommers (Eds.), Social networking and education: Global perspectives (pp. 225-238). Cham: Springer.

Krutka, D. G., Bergman, D. J., Flores, R., Mason, K., \& Jack, A. R. (2014). Microblogging about teaching: Nurturing participatory cultures through collaborative online reflection with pre-service teachers. Teaching and Teacher Education, 40, 83-93. doi:10.1016/j.tate.2014.02.002

Lampe, C., Wohn, D. Y., Vitak, J., Ellison, N. B., \& Wash, R. (2011). Student use of Facebook for organizing collaborative classroom activities. International Journal of Computer-Supported Collaborative Learning, 6(3), 329-347. doi:10.1007/s11412-011-9115-y

Lim, J., \& Richardson, J. C. (2016). Exploring the effects of students' social networking experience on social presence and perceptions of using SNSs for educational purposes. The Internet and Higher Education, 29, 31-39. doi:10.1016/j.iheduc.2015.12.001

Lin, P.-C., Hou, H.-T., Wang, S.-M., \& Chang, K.-E. (2013). Analyzing knowledge dimensions and cognitive process of a project-based online discussion instructional activity using Facebook in an adult and continuing education course. Computers \& Education, 60(1), 110-121. doi:10.1016/j.compedu.2012.07.017

Lockyer, L., \& Patterson, J. (2008). Integrating social networking technologies in education: A case study of a formal learning environment. In P. Diaz, Kinshuk, I. Aedo, \& E. Mora (Eds.), Proceedings of the Eighth IEEE International Conference on Advanced Learning Technologies (pp. 529-533). Los Alamitos, CA: IEEE Computer Society. Retrieved from http://citeseerx.ist.psu.edu/viewdoc/download?doi=10.1.1.453.3201\&rep=rep1\&type=pdf

Madge, C., Meek, J., Wellens, J., \& Hooley, T. (2009). Facebook, social integration and informal learning at university: 'It is more for socialising and talking to friends about work than for actually doing work’. Learning, Media and Technology, 34(2), 141-155. doi:10.1080/17439880902923606

Manca, S., \& Ranieri, M. (2013). Is it a tool suitable for learning? A critical review of the literature on Facebook as a technology-enhanced learning environment. Journal of Computer Assisted Learning, 29(6), 487-504. doi:10.1111/jcal.12007

Manca, S., \& Ranieri, M. (2015). Implications of social network sites for teaching and learning. Where we are and where we want to go. Education and Information Technologies, 1-18. doi:10.1007/s10639-015-9429-X

Manca, S., \& Ranieri, M. (2016). "Yes for sharing, no for teaching!”: Social media in academic practices. The Internet and Higher Education, 29, 63-74. doi:10.1016/j.iheduc.2015.12.004

McCarthy, J. (2010). Blended learning environments: Using social networking sites to enhance the first year experience. Australasian Journal of Educational Technology, 26(6), 729-740. doi:10.14742/ajet.1039

Mellor, S. (2015). Australian reflections on learning to be citizens in and with the social web. In B. D. Loader, A. Vromen, \& M. Xenos (Eds.), The networked young citizen: Social media, political participation and civic engagement (pp. 107-130). New York, NY: Routledge.

Merchant, G. (2012). Unravelling the social network: theory and research. Learning, Media and Technology, 37(1), 4-19. doi:10.1080/17439884.2011.567992

Mirabolghasemi, M., Iahad, N. A., \& Rahim, N. Z. A. (2016). Students’ perception towards the potential and barriers of social network sites in higher education. In T. Issa, P. Isaias, \& P. Kommers (Eds.), Social networking and education: Global perspectives (pp. 41-49). Cham: Springer. 
Oliver-Hoyo, M., \& Allen, D. (2006). The use of triangulation methods in qualitative educational research. Journal of College Science Teaching, 35(4), 42-47. Retrieved from http://www.nsta.org/store/product_detail.aspx?id=10.2505/4/jcst06_035_04_42

Pachler, N., Ranieri, M., Manca, S., \& Cook, J. (2012). Editorial: Social networking and mobile learning. British Journal of Educational Technology, 43(5), 707-710. doi:10.1111/j.1467-8535.2012.01365.x

Park, S. Y., Cha, S.-B., Lim, K., \& Jung, S.-H. (2014). The relationship between university student learning outcomes and participation in social network services, social acceptance and attitude towards school life. British Journal of Educational Technology, 45(1), 97-111. doi:10.1111/bjet.12013

Patton, M. Q. (2002). Qualitative research \& evaluation methods. London: Sage.

Pervaiz, S. (2016). The advantages and risks of using social networking in higher education in Pakistan. In T. Issa, P. Isaias \& P. Kommers (Eds.), Social networking and education: Global perspectives (pp. 83-97). Cham: Springer.

Prensky, M. (2001). Digital natives, digital immigrants part 1. On the Horizon, 9(5), 1-6. doi:10.1108/10748120110424816

Raacke, J., \& Bonds-Raacke, J. (2008). MySpace and Facebook: Applying the uses and gratifications theory to exploring friend-networking sites. CyberPsychology \& Behavior, 11(2), 169-174. doi:10.1089/cpb.2007.0056

Ranieri, M., Manca, S., \& Fini, A. (2012). Why (and how) do teachers engage in social networks? An exploratory study of professional use of Facebook and its implications for lifelong learning. British Journal of Educational Technology, 43(5), 754-769. doi:10.1111/j.1467-8535.2012.01356.x

Reiners, T., \& Alexander, P. (2013). Social network perception alignment of e-recruiters and potential applicants. In Proceedings of the 46th Hawaii International Conference on System Sciences (HICSS 2013) (pp. 4576-4585). Los Alamitos, CA: IEEE Computer Society. doi:10.1109/HICSS.2013.490

Roblyer, M. D., McDaniel, M., Webb, M., Herman, J., \& Witty, J. V. (2010). Findings on Facebook in higher education: A comparison of college faculty and student uses and perceptions of social networking sites. The Internet and Higher Education, 13(3), 134-140. doi:10.1016/j.iheduc.2010.03.002

Rossman, G. B., \& Rallis, S. F. (2003). Learning in the field: An introduction to qualitative research. Thousand Oaks, CA: Sage.

Sánchez, R. A., Cortijo, V., \& Javed, U. (2014). Students’ perceptions of Facebook for academic purposes. Computers \& Education, 70, 138-149. doi:10.1016/j.compedu.2013.08.012

Selwyn, N. (2009). Faceworking: Exploring students' education-related use of Facebook. Learning, Media and Technology, 34(2), 157-174. doi:10.1080/17439880902923622

Selwyn, N., \& Grant, L. (2009). Researching the realities of social software use - an introduction. Learning, Media and Technology, 34(2), 79-86. doi:10.1080/17439880902921907

Smith, D. K. (2014). iTube, YouTube, WeTube: Social media videos in chemistry education and outreach. Journal of Chemical Education, 91(10), 1594-1599. doi:10.1021/ed400715s

Statista. (2016). Number of monthly active Facebook users worldwide as of 1st quarter 2016 (in millions). Retrieved July 25, 2016, from http://www.statista.com/statistics/264810/number-of-monthly-activefacebook-users-worldwide/

Strijbos, J.-W., Martens, R. L., Prins, F. J., \& Jochems, W. M. G. (2006). Content analysis: What are they talking about? Computers \& Education, 46(1), 29-48. doi:10.1016/j.compedu.2005.04.002

Teo, T., Kabakçı Yurdakul, I., \& Ursavaş, Ö. F. (2014). Exploring the digital natives among pre-service teachers in Turkey: A cross-cultural validation of the digital native assessment scale. Interactive Learning Environments, 24(6), 1231-1244. doi:10.1080/10494820.2014.980275

Thelwall, M., \& Kousha, K. (2014). Academia.edu: Social network or academic network? Journal of the Association for Information Science and Technology, 65(4), 721-731. doi:10.1002/asi.23038

Viera, A. J., \& Garrett, J. M. (2005). Understanding interobserver agreement: The kappa statistic. Family Medicine, 37(5), 360-363. Retrieved from http://www.stfm.org/Portals/49/Documents/FMPDF/FamilyMedicineVol37Issue5Viera360.pdf

Wang, Q., Woo, H. L., Quek, C. L., Yang, Y., \& Liu, M. (2012). Using the Facebook group as a learning management system: An exploratory study. British Journal of Educational Technology, 43(3), 428438. doi:10.1111/j.1467-8535.2011.01195.x

Weisgerber, C., \& Butler, S. (2010). Editor’s introduction: Special issue on communication pedagogy in the age of social media. Electronic Journal of Communication, 20(1-2), 1. Retrieved from http://www.cios.org/www/ejc/v20n12toc.htm - introduction

Yıldırım, A., \& Şimşek, H. (2005). Qualitative research methods in social sciences. Ankara: Seçkin Publishing. 
Corresponding author: Murat Akçayır, muratakcayir@gmail.com

Australasian Journal of Educational Technology (c) 2017.

Please cite as: Akçayır, M. (2017). What do students think about SNSs in education? University students’ perceptions, expectations, and concerns regarding educational uses of SNSs. Australasian Journal of Educational Technology, 33(5), 91-106. https://doi.org/10.14742/ajet.3097 